\title{
RESPONSE BY ANTIBODIES TO TISSUE ANTIGENS IN THE COURSE OF RHEUMATIC FEVER
}

\author{
BY \\ V. WAGNER AND V. REJHOLEC \\ STATISTICAL EVALUATION BY V. MALY \\ TECHNICAL ASSISTANCE BY A. SOVAKOVA, M. MOTLIKOVA, E. HALLEROVA \\ From the Institute of Medical Microbiology, Charles University, Plzen, \\ the Research Institute of Rheumatic Diseases, Prague, and the \\ Institute of Public Health Organization, Charles University, Prague
}

(RECEIVED FOR PUbLiCATION AUgUST 13, 1956)

Weintraud (1913) was the first to envisage the possibility that tissue alterations in rheumatic patients may be due to a pathogenic anaphylactic reaction, but at that time it was not possible to verify his hypothesis by laboratory tests. The toxic properties of sera from rheumatic fever patients were first experimentally demonstrated by Ramsdell and Davidsohn (1930), and Klujeva and Bobritzkaja (1934). Brokman, Brill, and Frendzel (1937) found in the sera of rheumatic patients antibodies which gave a complement-fixation reaction with organs from children who had died with rheumatism. Coburn and Pauli (1939) found in the sera of patients in the acute stage of rheumatic fever a precipitin which reacted to an antigen which had been present in the blood before the onset of the attack. Their findings were partially corroborated by Wedum and Wedum (1946), but were questioned by Fischel and Pauli (1949).

Auto-antibodies to an aqueous extract of myocardium were demonstrated by Cavelti (1945) by means of collodion particle agglutination in a high proportion of rheumatic fever cases. Lippman, Cameron, and Campbell (1950) detected them in the sera of nephritic patients and proved their cytotic effects on myocardial tissue cultures. Lansbury, Crosby, and Bello (1950) found in the sera of patients with rheumatoid arthritis antibodies which would bind with extracts from pathological and normal tissues. Rejholec, Vančura, Wagner, and Mandlikova (1952) demonstrated antibody to myocardium in the blood of nephritic patients by means of collodion particle agglutination; Rejholec, Wagner, and Mandlikova (1952) and Rejholec and Wagner (1955) also showed them by the same method in patients with rheumatic fever. Osler, Hardy, and Sharp
(1954), using alcoholic extract of human heart for antigen, observed complement-fixation reactions in 50 per cent. of rheumatic patients, but also in 20 per cent. of controls. Vorlaender (1952), and Vorlaender, Fitting, and Blankenheim (1954) demonstrated auto-antibodies in several patients with rheumatic fever by the technique of absorption and haemagglutination of erythrocytes sensitized witlo artery-wall antigen. They observed a certaik parallelism with the course of the disease, althoug the number of their cases was small. Their findings were positive in the subchronic stage of the disease and negative in the acute phase. Steffen (1954a, b), Steffen and Rosak (1955), and Steffen and Schindler (1955) developed an indirect serological method of demonstrating auto-antibodies to connective tissue in rheumatism by absorbing the antiglobulin serum.

On the other hand, Fischel and Pauli (1949) failed to find antibody in rheumatism by the technique of collodion particle agglutination. It should be noted that Cavelti himself and subsequent investigators (McKee and Swineford, 1951; Peck and Thomas, 1948; Humphrey, 1948) were unable to repeat his work.

The present investigation was undertaken to $ᄋ$ verify the finding of auto-antibodies in the course of rheumatic fever, and to establish whether there is an interdependence between the clinically demonstrable involvement of different organs and tissues and the $\sigma$ occurrence of antibody, and whether the presence $N$ and the level of auto-antibodies may serve as an index of disease activity. Blood samples were 0 tested at short intervals during periods of hospitalization for the presence of antibodies to five types of tissue. The results were then compared with $\stackrel{\mathcal{D}}{\rightarrow}$ parallel clinical observations. 


\section{Material and Methods}

Preparation of Antigens. - Tissues for antigen extraction were taken from dead bodies, preferably those killed by accident; those dying from infection were excluded. The time expired since the death is of importance; it must not exceed 18 hours, and the body must be kept at $4^{\circ} \mathrm{C}$. Like Lange, Gold, and Weiner (1949) we obtained the best results with tissues from children and juveniles. We selected those types of tissue which most frequently suffer in the course of the rheumatic process: myocardium ("M"), valves with connective tissue of the heart ("V"), subcutaneous tissue ("ST"), skin ("S"), and joint capsule ("JC").

The tissues were minced and each small portion was stored in a separate container at $-18^{\circ} \mathrm{C}$. Only one container at a time was taken from the refrigerator for processing, and it was never used for longer than one day. Thus we avoided the repeated freezing and unfreezing of tissues which in our experience influences the stability of tissue antigen very unfavourably. At $-18^{\circ} \mathrm{C}$. the tissues could be kept unspoiled for weeks and even months.

After unfreezing, the tissues were ground aseptically. The homogenate was suspended in a $1: 40$ solution (Wagner, 1954), always freshly prepared and composed of $9.6 \mathrm{~g}$. $\mathrm{NaCl}, 0.4 \mathrm{~g} . \mathrm{CaCl}_{2}$, and $0.1 \mathrm{~g}$. $\mathrm{NaHCO}_{3},{ }^{*}$ with the addition of redistilled water up to $1,000 \mathrm{ml}$. After vigorous shaking, the suspension was incubated for 15 minutes at room temperature and then centrifuged. The supernatant fluid, slightly opalescent, was mixed in equal parts with a collodion suspension prepared by the method of Cavelti (1947), and diluted by addition of a saline solution as above; the final density of the collodion suspension was equal to Degree 2 of the scale described by McFarland (1907). The nitrocellulose for the preparation of collodion particles had to be of Grade 22 viscosity, measured by the Wassag method (other grades proved unsuitable). $\dagger$ The mixture of collodion suspension and antigen was incubated at room temperature for 1 hour.

Before being used in experiments, each tissue extract was tested with several sera of normal humans (blood donors), as well as with a diagnostic Group $\mathbf{O}$ serum possessing a titre of at least $1: 256$. Only those tissues which had proved stable in these preliminary tests were used in the experiments proper. Sometimes only one out of many cadavers gave antigens suitable for collodion agglutination. The least stable antigens were those from the cardiac valves with connective tissue of the heart.

Agglutination Tests.-Serum dilutions in serial twofold steps, from $1: 2$ to $1: 256$, were made with the same saline solution in tubes of an inner diameter of about $8 \mathrm{~mm}$. To every serum dilution of volume $0.25 \mathrm{ml}$. was added an equal volume of collodion particles coated

* These chemicals were of the Lachema, Brno, make, and of the pro analysi grade.

+ We employed nitrocellulose E 620 produced by Explosia, Semtin, Czechoslovakia. The collodion described in the Pharmacopoeia gave markedly inconsistent results. with antigen. After vigorous shaking, incubation lasting $90 \mathrm{~min}$. at room temperature, and centrifugation at 1,500 r.p.m. for $3 \mathrm{~min}$., the reactions were read while the upper part of the tube was lightly held and the base gently tapped to stir up the sediment. The dilution which showed an agglutination visible to the naked eye, even if only slightly granular, was recorded as the final titre.

Control Tests.-The following tests were always carried out in the same conditions:

(1) With bare collodion particles mixed with isotonic saline instead of serum;

(2) With collodion particles coated with antigen and mixed with saline;

(3) With collodion particles coated with antigen and mixed with a negative serum-the last-named tests were done in each series of examinations with several sera from different blood donors and healthy members of the sanitary staff-diluted as in the test proper;

(4) With collodion particles without antigen, mixed with the serum from a rheumatic patient, similarly diluted.

The results of the tests proper were recorded and used for the final evaluation, provided no agglutination could be detected in any of the control tests.

All the serological tests were carried out by one of us (W.V.) in ignorance of the diagnosis and the clinical state of the patient.

Blood Samples for Processing.-These were drawn from the cubital vein. The serum was separated from the clot aseptically as soon as possible upon coagulation. The patients' sera were stored at $-25^{\circ} \mathrm{C}$. and dispatched by train once a week to the laboratory; the temperature at which they were kept on the journey, which lasted for about $24 \mathrm{hrs}$, was outside our control. The control sera were stored directly in the laboratory.

Selection and Examination of Patients. - 38 patients (20 male and 18 female) were hospitalized in the wards of the Research Institute of Rheumatic Diseases, Prague, between February, 1954, and June, 1955, with the diagnosis of rheumatic fever. Four of them were hospitalized twice in this period and have been listed in some of our Tables as two independent cases, making a total of 42 . The average age of the women was 18 years (range 10 to 39) and of the men 17 (range 6 to 43).

The diagnosis had been made by accepted criteria on the basis of past history, objective clinical examination, and several laboratory tests, and was constantly checked during the course of the disease.

The patients were first examined on the day of admission, before the institution of therapy. On this day, blood samples for the serological tests and for the erythrocyte sedimentation rate and Weltman reaction were taken, an electrocardiograph was made, the temperature was recorded, and a nasopharyngeal swab was taken for bacteriological tests. In taking the medical history, special stress was put on the chronological sequence of the preceding infectious phase, the first signs of rheumatic fever, and the treatment before admission. 
Thirty patients were undergoing a first attack; the rest the second or a late acute episode.

Twenty patients had not been treated at all before admission, not even by rest in bed. In this group, the average interval between the first signs of rheumatic fever and hospitalization was 10.4 days (three cases 2 days, two cases 3 days, seven cases 4 to 7 days, five cases 8 to 14 days, three cases longer than 14 days).

Eight patients had been treated before hospitalization by rest in bed and anti-rheumatic medicaments in insufficient doses (less than $5 \mathrm{~g}$. sodium salicylate or less than $1 \mathrm{~g}$. amidopyrin daily). In this group, the mean interval between the first signs of disease and hospitalization was 14 days and the average duration of medication $11 \cdot 5$ days.

Seven patients had been treated by $f_{\mathrm{L}} \mathrm{ll}$ doses of salicylate or amidopyrin and by absolute rest in bed. The average interval between the onset of disease and hospitalization was 16 days, including an average of 14 days' adequate therapy.

Seven patients who had been transferred from other hospitals were all in a late stage of the disease.

\section{Treatment}

Strictly controlled rest in bed was maintained till the signs of disease activity subsided.

Salicylate.-26 patients received appropriate doses, which in the acute phase were never less than $10 \mathrm{~g}$. in $24 \mathrm{hrs}$.

Amidopyrin.-Seven patients received daily doses of at least $2 \mathrm{~g}$.

For nine patients these two drugs were combined or alternated, owing especially to the intolerance of salicylate.
Hormone Therapy.-This was instituted in five patients in whom the salicylate or amidopyrin therapy seemed contra-indicated or proved inefficient or was not supported. In three cases ACTH was administered and in two oral cortisone. No patient was treated exclusively with hormones.

Antibiotics.-Penicillin or other antibiotics were given sixteen times, solely to suppress the symptoms of the infection of upper respiratory tracts or upon detection of beta-haemolytic streptococcus in the nasopharyngeal mucus.

In all cases the treatment given to the patients during hospitalization may thus be regarded as adequate, in spite of certain individual differences in dosage and type of medicament. None of the patients was given digitalin at any stage.

\section{Results}

In the course of the present investigation, 307 blood samples from rheumatic patients in different stages of disease and several hundred blood samples from normal persons were examined. The lastmentioned showed no positive reaction whatever.

Fig. 1 shows percentages of patients with positive findings of auto-antibodies to individual antigens, irrespective of their level. The findings are charted in periods of 4 days, beginning with the day wheno therapy was started in the ward. The results obtained with skin antigen are omitted, as theye resemble very closely those obtained with subcutaneous tissue. The average erythrocyte sedi-

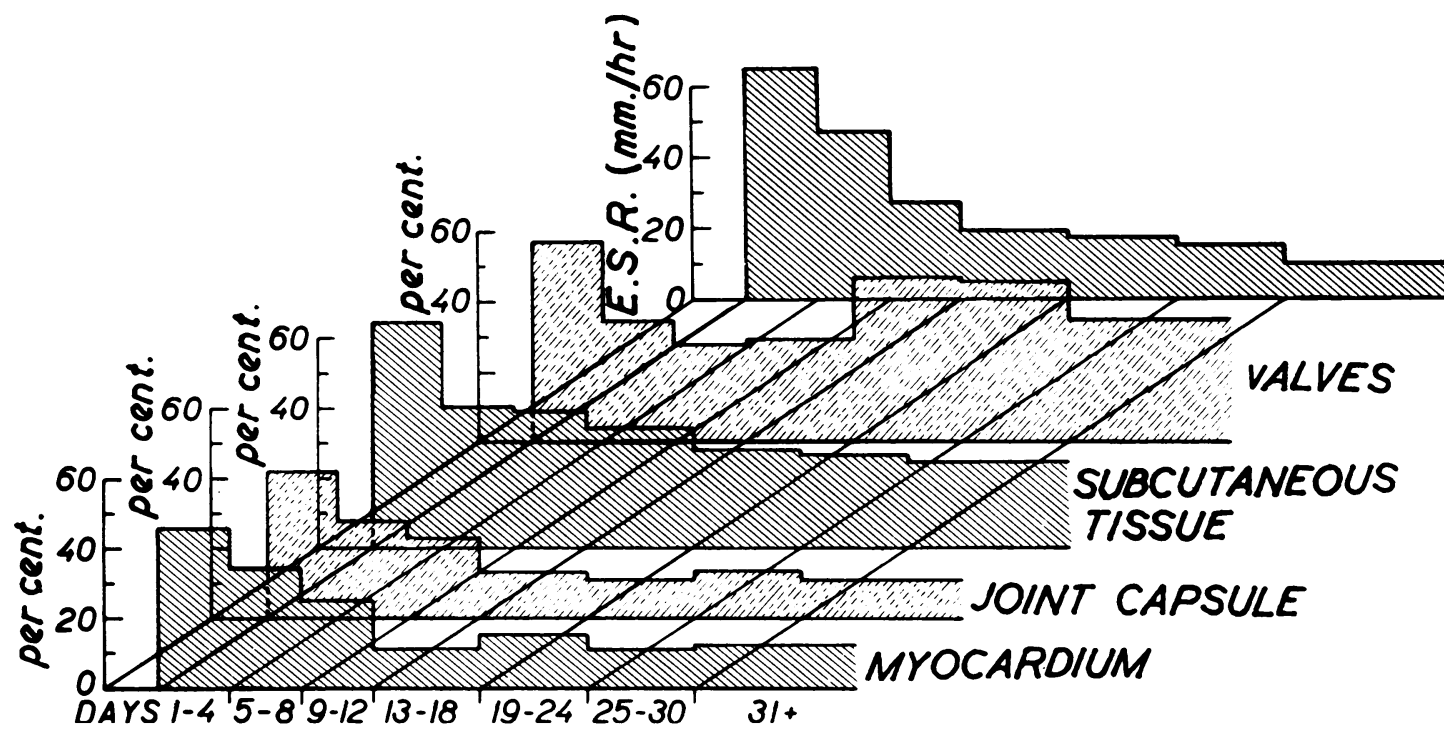

Fig. 1.-Percentages of patients showing auto-antibodies (at whatever level) to different antigens in periods of 4 days, and, for comparison, mean erythrocyte sedimentation rates from the same blood samples. 
mentation rate in the first hour is also given for comparison.

The total from which the percentages were computed was not a constant, but decreased steadily especially after the 19th day, owing to the gradual discharge of healed patients. Thereafter, the total consisted of patients who had suffered a re-infection or in whom the results of medication were not satisfactory.

The rate of positive reactions to individual antigens in the first few days after admission was between 40 and 60 per cent. and decreased gradually. About the 19th day a rebound may set in; for several types of antigen the increase in the rate of positive cases is insignificant (myocardium, joint capsules) or is altogether lacking (subcutaneous tissue), but for other types (valvular antigen) it is appreciable.

Universal positivity of the sera, i.e. cases in which antibody to any type of antigen was found, is not recorded here; it comprised 80.7 per cent. of all sera investigated in the first few days of the disease.

Table I indicates titres of antibody recorded on admission, distributed according to the treatment received before hospitalization. The patients are grouped according to the highest titre of antibody shown, irrespective of the type of antigen responsible for the reaction. It appears that patients who had not been treated at all before hospitalization mostly had titres of $1: 16$ or more, that patients adequately treated showed rather lower titres, and that patients inadequately treated stood roughly in the middle.

By dividing the titres into low (up to $1: 8$ inclusive) and high (from $1: 16$ upwards), as indicated by brackets in Table I, we obtained a six-fold table of contingencies, to ascertain whether the titre level was related to therapy. Evaluation by the $\chi^{2}$ test has shown that the difference between the predominantly high titres of the untreated or inadequately treated cases and the predominantly low

TABLE I

CORRELATION BETWEEN ANTIBODY TITRE ON ADMISSION AND TREATMENT BEFORE HOSPITALIZATION

\begin{tabular}{|c|c|c|c|c|}
\hline \multirow{2}{*}{$\begin{array}{c}\text { Antibody } \\
\text { Titre }\end{array}$} & \multicolumn{3}{|c|}{ Treatment before Hospitalization } & \multirow{2}{*}{ Tota } \\
\hline & None & Inadequate & Adequate & \\
\hline $\begin{array}{l}\text { Negative } \\
1: 4 \\
1: 8\end{array}$ & $\left.\begin{array}{l}2 \\
0 \\
1\end{array}\right\} 3$ & $\left.\begin{array}{l}2 \\
0 \\
0\end{array}\right\}$ & $\left.\begin{array}{l}1 \\
1 \\
3\end{array}\right) 5$ & 10 \\
\hline $\begin{array}{l:l}1 & : 16 \\
1 & 32 \\
1 & : 64\end{array}$ & \begin{tabular}{l|l}
5 & \\
8 & 17 \\
4 &
\end{tabular} & \begin{tabular}{l|l}
3 & \\
2 & 6 \\
1 & 6
\end{tabular} & $\left.\begin{array}{l}1 \\
1 \\
0\end{array}\right) 2$ & 25 \\
\hline Total* $^{*}$ & 20 & 8 & 7 & $35^{*}$ \\
\hline
\end{tabular}

* Not including three patients transferred from other hospitals. titres of the adequately treated cases is statistically significant at the 2 per cent. level.

Table II shows the percentages of sera which reacted positively to a certain type of antigen and also contained antibody to another type of antigen. For example, of all those sera which in our tests reacted positively to myocardium, 93.1 per cent. also reacted simultaneously to valves, 95.7 per cent. to subcutaneous tissue antigen, and so on. In other words, only 6.9 per cent. of sera reacting with myocardium did not react with valves, only $4 \cdot 3$ per cent. did not react with subcutaneous tissue, and so on. The sera which, while reacting to one type of antigen, did not react to a certain other type, ranged from $4 \cdot 3$ to $27 \cdot 1$ per cent. This means that, although in a given serum one type of antibody is not necessarily accompanied by all other types, in most cases the coexistence of different types of antibody may be assumed as highly probable if one type has been detected.

TABLE II

CORRELATION BETWEEN OCCURRENCE OF AUTOANTIBODIES AND OF DIFFERENT ANTIGENS IN SEPARATE BLOOD SAMPLES (PER CENT.)

\begin{tabular}{|c|c|c|c|c|c|}
\hline \multirow{2}{*}{$\begin{array}{c}\text { Sera } \\
\text { reacting } \\
\text { Positively } \\
\text { with }\end{array}$} & \multicolumn{5}{|c|}{$\begin{array}{l}\text { Percentages of Sera also reacting } \\
\text { Positively with }\end{array}$} \\
\hline & $\begin{array}{l}\text { Myo- } \\
\text { cardium }\end{array}$ & Valves & $\begin{array}{c}\text { Sub- } \\
\text { cutaneous } \\
\text { Tissue }\end{array}$ & Skin & $\begin{array}{l}\text { Joint } \\
\text { Capsule }\end{array}$ \\
\hline Myocardium. & - & $93 \cdot 1$ & $95 \cdot 7$ & $88 \cdot 5$ & $89 \cdot 0$ \\
\hline Valves & $72 \cdot 9$ & - & $84 \cdot 4$ & $77 \cdot 8$ & $74 \cdot 4$ \\
\hline $\begin{array}{c}\text { Subcutaneous } \\
\text { Tissue }\end{array}$ & $82 \cdot 2$ & $89 \cdot 1$ & 一 & $79 \cdot 5$ & $79 \cdot 7$ \\
\hline Skin .. & $85 \cdot 4$ & $93 \cdot 6$ & $92 \cdot 6$ & - & $87 \cdot 1$ \\
\hline Joint Capsule & $88 \cdot 3$ & $93 \cdot 9$ & $93 \cdot 2$ & $92 \cdot 8$ & - \\
\hline
\end{tabular}

Fig. 2 (overleaf) represents the distribution of patients according to the highest titre of antibody to separate antigens reached at any period. Patients with consistently negative findings for a definite type of antibody ranged from 2.6 per cent. (for antibody to subcutaneous tissue) to $29 \cdot 8$ per cent. (for antibody to joint capsule).

Thus the subcutaneous tissue antigen seems to have been responsible for the highest production of antibody detected, as well as for its highest concentrations ( $c f$. the number and rate of titres exceeding $1: 16$ ); after it come valves, myocardium, skin, and joint capsule in that order. Fig. 2 shows that in some patients a certain type of antibody was always lacking, but there was none who did not harbour in the blood one or other of the antibody types studied, even if these were seen only once 

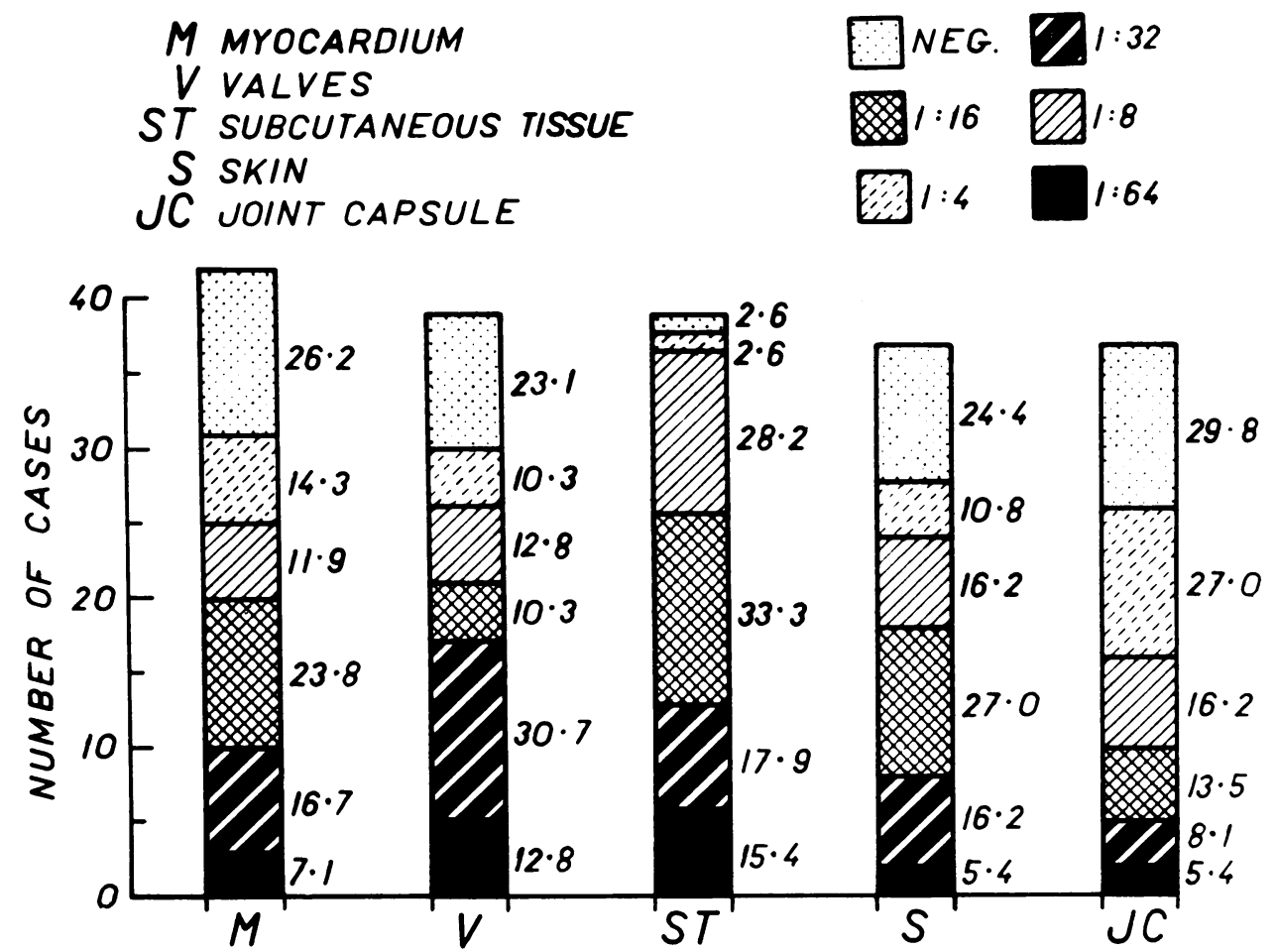

Fig. 2.-Absolute and percentile distribution of patients according to highest antibody titres to separate antigens reached at whateve stage of disease.

Patients hospitalized twice are shown as two cases. For technical reasons a few sera could not be tested for all types of antibody; this accounts for the differing lengths of the columns.

during the period of hospitalization. The seeming incongruity of the values in Fig. 2 with the lower percentages in Fig. 1 is due to the fact that Fig. 1 gives averages of separate short periods, whilst Fig. 2 shows a selection of all the blood samples of each patient.

Fig. 3 (opposite) shows cases investigated from the point of view of presence or absence of clinically demonstrable pathological findings in the heart. In the upper section (A), the cases are ranged according to the highest titre of antibody of any type ascertained at any phase of the disease. Only three cases of all those with heart damage had antibody titres under $1: 32$. Inversely, only four cases lacking clinical signs of carditis had titres of $1: 32$ or more.

The lower section (B) shows only antibodies to myocardium and to valves. Clinically demonstrable heart lesions and high antibody levels tend to parallel each other, though the pattern is not so clear-cut as in Section A, in which all five types of antibody are considered. A possible explanation of this divergence is suggested below.
Table III gives the data for correlating fresh heart lesions with rises in antibody titre caused by recurrence of disease during hospitalization. Only those patients were taken into account who continued to be tested for antibody after the 19th day of hospitalization; this means that the less severe cases which had been discharged from hospital are excluded.

TABLE III

CORRELATION BETWEEN RE-INFECTION, RISE IN
ANTIBODY TITRE, AND FRESH HEART DAMAGE
AFTER 19TH DAY OF HOSPITALIZATION

\begin{tabular}{|c|c|c|c|c|c|c|}
\hline \multirow[b]{2}{*}{ Re-infection } & & \multicolumn{2}{|c|}{ Rise in Titre } & \multicolumn{2}{|c|}{ No Rise in Titre } & \multirow[b]{2}{*}{ Total } \\
\hline & & $\begin{array}{c}\text { With } \\
\text { Fresh } \\
\text { Heart } \\
\text { Damage }\end{array}$ & $\begin{array}{c}\text { Without } \\
\text { Fresh } \\
\text { Heart } \\
\text { Damage }\end{array}$ & $\begin{array}{c}\text { With } \\
\text { Fresh } \\
\text { Heart } \\
\text { Damage }\end{array}$ & $\begin{array}{c}\text { Without } \\
\text { Fresh } \\
\text { Heart } \\
\text { Damage }\end{array}$ & \\
\hline Ascertained & . & 5 & 0 & 0 & 2 & 7 \\
\hline Not Ascertained & . & 0 & 3 & 2 & 18 & 23 \\
\hline Total . . & $\ldots$ & 5 & 3 & 2 & 20 & 30 \\
\hline
\end{tabular}

Notes: Only substantial rises, i.e. from a lower titre (up to $1: 16$ ) to a higher titre (from $1: 32$ upwards) were considered. Pathological changes in the heart ascertained either by electrocardiogram or by auscultation. 


\section{MANIFEST SIGNS OF CARDITIS}
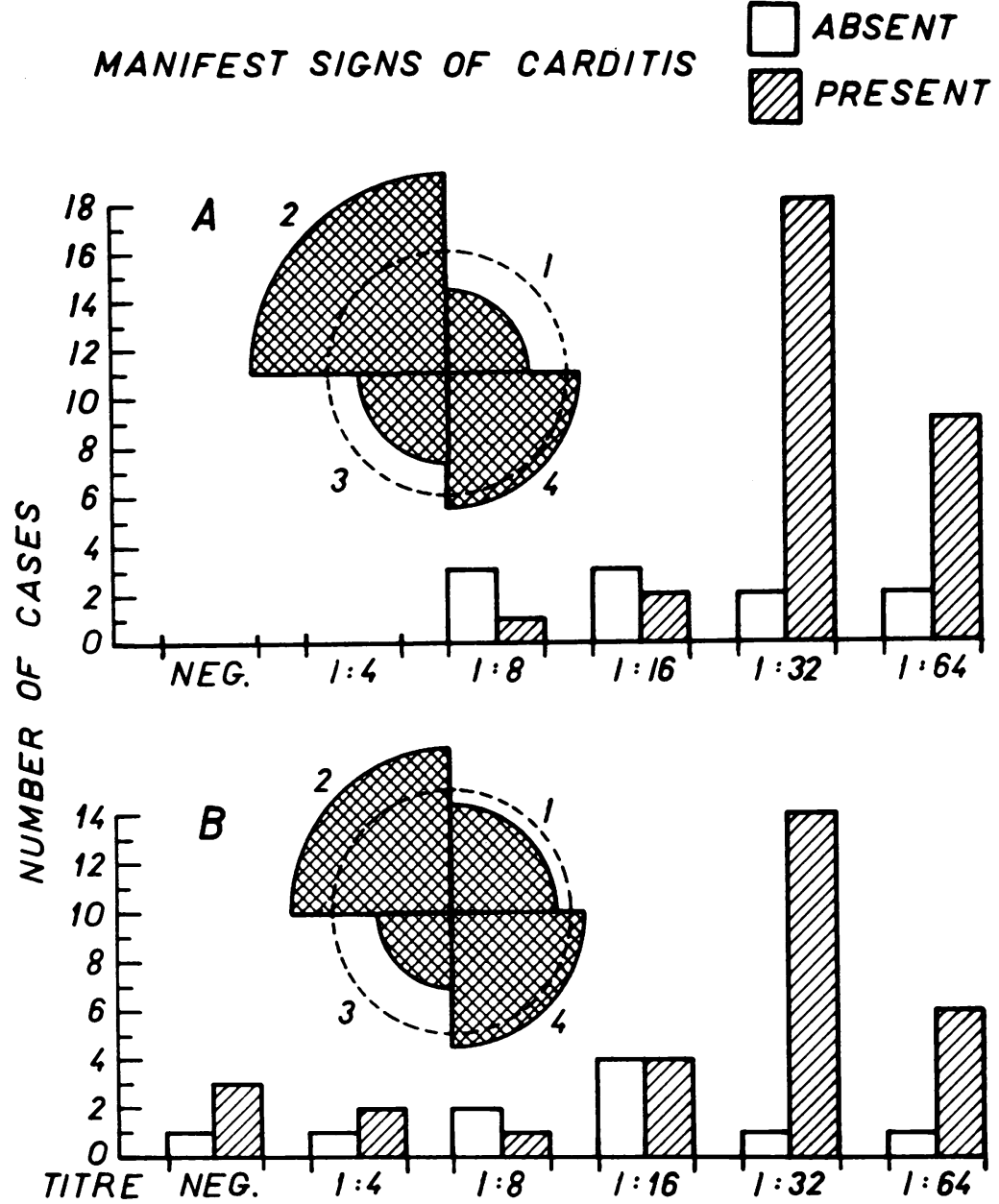

Fig. 3.-Occurrence of auto-antibodies in different titres, related to clinical manifestation of carditis.

(A) Antibodies to all five selected types of antigen. (B) Antibodies to heart tissue antigens only.

Quadrant 1: Cases with high antibody titres (above 1:16) without signs of carditis.

Quadrant 2: Cases with high titres and signs of carditis.

Quadrant 3: Cases with low titres and signs of carditis.

Quadrant 4: Cases with low titres without signs of carditis.

Dotted Circle: The distribution of these four variants which would be expected if carditis were independent of the antibody titre.

Table III serves to evaluate the significance of the results obtained by the $\chi^{2}$ test. All three values of $\chi^{2}$ appear to be significant at the 1 per cent. level. In all the thirty cases which were followed-up, only one had a titre of $1: 16$ on the 20th day of hospitalization; in two patients the titre was $1: 8$ and in one it was $1: 4$, the remaining eighteen being negative.

However, after the 19th day, the titres began to rise ( $c f$. also Fig. 1) and in five patients out of seven with clinically ascertainable re-infection they rose rapidly. Simultaneously, these five patients showed fresh heart damage, but no such damage was detected in the two patients whose titres did not rise. Among patients without ascertainable re-infection, eighteen cases showed no substantial rise in titre-though a moderate rise (up to $1: 8$ ) was recorded in nine of them-neither did their heart condition deteriorate.

Only in two patients did the heart condition become worse without any corresponding substantial rise in the level of antibody. Inversely, a substantial rise was recorded in three patients in whom no heart damage could be detected clinically. No re-infection was found in these five patients. 


\section{Discussion}

The significance of the auto-antibodies demonstrated in certain diseases has not yet been elucidated, though in some the appearance of antibody is known to precede the clinical manifestations, and there is a striking interdependence of the antibody concentration and organic damage. The aim of the present study was to correlate levels of antitissue antibody with clinical manifestations of rheumatic fever. Some but not all of the observed cases showed a congruity between the serological findings and the clinical pattern, and we therefore adopted statistical methods of evaluation. The explanation of divergent results in particular cases may lie either in the nature of the patient or in the method used.

The occurrence of auto-antibodies to five selected types of tissue in the sera of patients with rheumatic fever was demonstrated by the collodion particle agglutination method. We found that the connective tissues are much less stable in collodion agglutination than the antigenic substances of the parenchymatous organs. Tissues from many cadavers did not give negative results in every control test. Since the tissue extracts used as antigen were not purified, their qualitative and quantitative composition was ignored, but, after weeks and even months of freezing, tissues taken from the same cadaver showed no change in antigenic properties, and this suggests that the common reagent remained the same, so that differences in the results must be due to the properties of the individual sera examined.

Another difficulty lay in the inherent properties of the antibodies themselves. Quite fresh sera, even from healthy subjects, may spontaneously agglutinate tissue antigens in low titres, but the same sera will give negative reactions if left standing for 24 hours. For this reason we never used the sera until 24 hours had elapsed, and the reliability of our findings has therefore not been prejudiced by this factor.

A further precaution was necessitated by the instability of the auto-antibodies, which, as we found in a series of trial experiments, disappear after a week if the sera are not kept at $-20^{\circ} \mathrm{C}$.; to accelerate freezing, it is even better to cool them to $-30^{\circ} \mathrm{C}$. The storing of sera for long periods at inadequately low temperatures may account for the negative findings reported by some authors (Fischel and Pauli, 1949). The thermolability of antibody makes the standardization of findings very difficult.

In spite of these reservations, the reported findings demonstrate convincingly the interdependence of the occurrence of auto-antibody and the presence of the disease process in the organism. Sera which reacted positively to at least one type of selected antigen made up 80.7 per cent. of the positive findings in the first 4 days of hospitalization. Thus in nearly 20 per cent. of cases no antibody was detected during this period, but it does not follow that this 20 per cent. were always negative, since antibody sometimes shows only in the later course of the disease. In no single case were antibodies not revealed at least once.

On the whole, the fall in the percentage of patients with positive antibodies roughly paralleled the length of time which had elapsed since admission to hospital. Though we could not organize a group of controls who were not adequately treated during hospitalization, we feel entitled to infer a correlation of positive findings with therapy. This tendency is exemplified by Table I which shows the treatment received before hospitalization. In our experience, cases untreated or inadequately treated before admission maintained high antibody levels in hospital longer than other patients. These observations suggest that the change in antibody concentration may be used as an index of adequacy of therapy.

From the discrepancies between the incidence of positive reactions by the same blood sample to different types of antigen (Table II) it follows that the sera of patients with rheumatic fever contain not one type of antibody only, but a whole spectrum of antibodies directed against different components of the examined tissues. In separate samples we observed every possible combination of reactions tó the antigens employed, high titres of antibody to one antigen and negative results to others. Several patients responded differently to the same type of antigen on different days. This phenomenon cannot be explained away simply by assuming quantitative differences in the single components of tissue antigens of different types. It seems more likely that different types of tissue differ qualitatively in their antigenic composition (Pressman, Sherman, and Korngold, 1951). Biochemical fractionation of the tissues is a necessary preliminary to the elucidation of this problem.

In eight cases out of thirty a rise in antibody production occurred after the 19th day of hospitalization. Re-infection contributed to this rise in five of the eight cases (Table III).

The levels of antitissue auto-antibody in each of the investigated patients were correlated with laboratory and clinical tests of disease activity, especially the Weltman reaction and the erythrocyte sedimentation rate. To some extent these results corresponded, but the significance of the presence and amount of antibody seems to differ from that of the other reactions. It seems, too, that auto- 
antibodies persist longer than other accepted criteria of disease activity. Histological findings of fresh Aschoff bodies in myocardia showing no clinical signs of disease prove that sub-clinical rheumatic activity persists in many convalescents. It would be useful to make a special study comparing these findings with the incidence of auto-antibodies. Until this aspect of the problem is examined, we may assume that the presence of auto-antibodies is a rough index of disease activity, latent or otherwise.

In order to examine the relationship between the incidence of antibodies and various tissue lesions, we investigated five different types of tissue on the assumption that different separate organs might be independently involved. The relationship between high titre levels of auto-antibody and clinical heart damage was found to be statistically significant, cases showing titres of $1: 32$ or more being extremely likely to show clinically demonstrable myocardial or valvular damage. The dependence of organic. lesions on the presence of antibodies in the serum is, however, not absolute, for the following reasons:

(1) A certain type of antibody may have been present in high concentration in the patient's serum before admission, but may have already been absorbed by the tissues (Sarre and Wirtz, 1939; Pressman, 1951) and be, therefore, no longer demonstrable in the blood. This localization of the antibody in the appropriate organ takes place very rapidly (Pressman, Eisen, and Fitzgerald, 1950). This observation is corrotorated by our own experience: one patient who showed a titre of $1: 32$ on admission was subsequently persistently negative, but the carditis resisted every form of therapy, and at necropsy, fresh myocardial and valvular lesions were found.

(2) Antibody may damage organs without producing clinical signs of involvement (Clark and Anderson, 1955).

(3) Salicylate therapy may cause a sero-negative reaction (Derick, Hitchcock, and Swift, 1928; Wagner and Zavazal, 1955) without presenting pathological changes in the heart tissue.

(4) Collodion agglutination may not intercept every type of antibody, and incomplete antibodies of various descriptions may thus escape detection.

The interdependence of the level of auto-antibody in the blood and the tissue lesions (Fig. 3 and Table III), relative though it is, seems to indicate that antibody in the blood must reach a certain concentration before it is able to penetrate the tissue and accumulate there in sufficient amounts to provoke changes that are clinically demonstrable. Theoretically, a reverse order of cause and effect can be envisaged. Antibody may appear in consequence of a pathological process which may already have taken its course in the tissue. The appearance of antibody might thus be a sort of secondary index and not the cause of the pathological process
(Vorlaender and others, 1954). In another series of tests (Wagner and Šeba, 1956), one of us observed a case of pemphigus in which a high concentration of antibody was detected in the patient's serum and bullae appeared on the skin on the following day, simultaneously with the shifting of auto-antibody from the blood into the blister fluid. This observation, like one previously made by Lippman and others (1950), as well as the analogy with immunohaematological processes, supports the hypothesis of the pathogenic effects of auto-antibody, though these hitherto fragmentary experiences cannot be extended to the rheumatic diseases in general.

Fig. 3 shows that patients with heart lesions may present low antibody titres to heart tissue antigens. A comparison of Fig. 3A with Fig. 3B shows that though the titre of antibody to subcutaneous tissue and skin tissue may be high, the titre to heart tissue may be low or even absent. At first sight these findings seem paradoxical, but perhaps these specific anti-heart tissue antibodies are immediately absorbed by the heart tissues in which their high concentration rapidly causes lesions; thus these specific heart antibodies disappear from the blood whilst other types of antibody remain.

\section{Summary}

The collodion agglutination method was applied to investigate anti-organal antibodies to antigens from human myocardium, valves, subcutaneous tissue, skin, and joint capsule. The examinations were carried out with sera from 38 hospital patients with rheumatic fever. The serological results were compared with the results of other laboratory and clinical examinations. The greatest attention was paid to the correlation of antibody with damage to myocardium and valves.

Antibody was found at least once in the blood of each patient, but the incidence of antibodies to single antigens ranged from 70.2 per cent. (to joint capsule antigen) to $97 \cdot 4$ per cent. '(to subcutaneous tissue antigen). During the first week of hospitalization 80.7 per cent. of patients were found to have antibody to at least one type of antigen in the blood.

The findings of anti-organal antibodies were compared with the therapy received before hospitalization. Patients who had been inadequately treated or not treated at all showed a higher incidence and higher levels of antibody. The interdependence between antibody findings and signs of heart damage was statistically significant, whether all five types of antibody or only the anti-myocardial and anti-valvular types were taken into account. Re-infection in the course of the disease made the titre rise in a statistically significant manner. A 
certain parallelism was seen between the antibody concentration and the activity of the rheumatoid process as measured by the erythrocyte sedimentation rate and Weltman reaction. On the other hand, antibody was not found at all in the very numerous control group of healthy subjects (blood donors and sanitary personnel).

\section{REFERENCES}

Brokman, H., Brill, J., and Frendzel, J. (1937). Klin. Wschr., 16, 502 .

Cavelti, P. A. (1945). Proc. Soc. exp. Biol. (N.Y.), 60, 379. (1947). J. Immunol., 57, 141

Clark, R. M., and Anderson, W. (1955). Amer. J. Path., 31, 809.

Coburn, A. F., and Pauli, R. H. (1939). J. exp. Med., 69, 143.

Derick, C. L., Hitchcock, C. H., and Swift, H. F. (1928). J. clin. Invest., 5, 427.

Fischel, E. E., and Pauli, R. H. (1949). J. exp. Med., 89, 669.

Humphrey, J. H. (1948). J. Path. Bact., 60, 211.

Klujeva and Bobritzkaja (1934). Acta rheumatol. (Amst.), 6 No. 20-21, Appendix, p. 4.

Lange, K., Gold, M. M. A.,, Weiner, D., and Simon, V. (1949). J. clin. Invest., 28, 50 .

Lansbury, J., Crosby, W. R., and Bello, C. T. (1950). Amer. J. med. Sci., $220,414$.

Lippman, R. W., Cameron, G., and Campbell, D. H. (1950). Proc. nat. Acad. Sci. (Wash.), 36, 576.

McFarland, J. (1907). J. Amer. med. Ass., 49, 1176.

McKee, K. T., and Swineford, O. (1951). Annals of the Rheumatic Diseases, 10, 116

Osler, A. G., Hardy, P. H., and Sharp, J. T. (1954). Amer. J. Syph., 38, 554.

Peck, J. L., and Thomas, L. (1948). Proc. Soc. exp. Biol. (N.Y.), 69,451 .

Pressman, D., Eisen, H. N., and Fitzgerald, P. J. (1950). J. Immunol. 64, 281 .

- and Sherman, B. (1951). Ibid., 67, 21.

,-- , and Korngold, L. (1951). Ibid., 67, 493.

Ramsdell, S. G., and Davidsohn, I. (1930). Ibid., 18, 473.

Rejholec, V., Vančura. A., Wagner, V., and Mandlikova, Z. (1952). Sborn. lék., 54, 195.

and Wagner, V.'(1955). Experientia, 11, 278.

- , and Mandlikova, Z. (1952). Sborn. lék., 54, 217.

Sarre, H., and Wirtz, H. (1939). Klin. Wschr., 18, 1548.

Steffen, C. (1954a). Wien. Z. inn. Med., 35, 422.

(1954b). Klin. Wschr., 33, 134.

- and Rosak, M. (1955). Wien. Z. inn. Med., 36, 40

- and Schindler, H. (1955). Schweiz. Z. allg. Path. Bakt. 18, 287.

Vorlaender, K. O. (1952). Z. ges. exp. Med., 120, 9.

, Fitting, W., and Blankenheim, H. (1954). Z. Rheumaforsch., 13, 276.

Wagner, V. (1954). Schweiz. Z. allg. Path. Bakt., 17, 94.

Wagner, Seba, G. (1956). Dermatologica (Basel), 112, 25 and Zavazal, V. (1955). Z. Immunforsch., 112, 260.

Wedum, A. G., and Wedum, B. G. (1946). Proc. Soc. exp. Biol. $(N . Y), 61,432$.

Weintraud, W. (1913). Berl. klin. Wschr., 50, 1381.

Réaction par des anticorps contre les antigenes des tissus au cours du rhumatisme articulaire aigu

RÉSUMÉ

La méthode d'agglutination au collodion fut employée pour rechercher les anticorps spécifiques aux antigenes provenant du myocarde, des valvules, du tissu souscutané, de la peau et de la capsule articulaire humains. Les examens furent effectués avec des sérums provenant de 38 malades hospitalisés, atteints de rhumatisme articulaire aigu. Les résultats sérologiques furent comparés avec les résultats d'autres examens cliniques et de laboratoire. On prêta la plus grande attention à la relation entre l'anticorps et le dommage myocardique et valvulaire.

Un anticorps fut trouvé au moins une fois dans le sang de chaque malade, mais le rapport des anticorps aux particuliers antigènes était compris entre 70,2\% (pour l'antigène de la capsule articulaire) et 97,4\% (pour l'antigène du tissu souscutané). Durant la première semaine d'hospitalisation $80,7 \%$ de malades se révélèrent avoir des anticorps contre au moins un type d'antigène du sang.

Les découvertes d'anticorps anti-organe furent considérées en relation avec le traitement avant l'hospitalisation. Les malades qui avaient été soignés insuffisamment ou pas du tout, avaient des anticorps plus souvent et en quantité plus élevée. L'interdependance entre les découvertes d'anticorps et les signes de lésion cardiaque était statistiquement significative, soit que l'on considérât les cinq types d'anticorps ou seulement les types antimyocardique et antivalvulaire. $\mathrm{La}$ re-infection durant la maladie faisait monter le titre d'une façon statistiquement significative. Un certain parallèle se montrait entre le taux d'anticorps et l'activité du processus rhumatismal, mésurée par la vitesse de sédimentation érythrocytaire et la réaction de Weltman. D'autre part, on n'a pas trouvé d'anticorps du tout parmi les très nombreux témoins (donneurs de sang et personne sanitaire).

Reacción por anticuerpos contra antigenos de los teïidos en el curso del reumatismo poliarticular agudo

SUMARIO

Con la ayuda del método de aglutinación al colodión se buscaron los anticuerpos específicos a los antígenos del miocardio, de las valvulas, del tejido subcutáneo, de la piel y de la cápsula articular humanos. Se investigaron sueros de 38 enfermos hospitalizados afectos de reumatismo poliarticular agudo. Los resultados serológicos fueron comparados a otros datos clínicos y de laboratorio. La correlación entre los anticuerpos y lao lesiones del miocardio y de las valvulas fué consideradar con un cuidado particular.

Un anticuerpo fué encontrado al menos una vez en la sangre de cada enfermo, pero la incidencia de los anticuerpos respecto a los antigenos particulares variaba de $70,2 \%$ (para el antígeno de la capsula articular) a 97,4\% (para el antígeno del rejido subcutaneo). Durante la primera semana de hospitalización el $80,7 \%$ de los enfermos reveló la presencia de anticuerpos contra a menos un tipo de antígeno en la sangre.

Los hallazgos de anticuerpos "anti-organos" particulares fueron considerados en relación con el tratamiento recibido antes de la hospitalizacion. Con un tratamiento anterior insuficiente o ausente, los anticuerpos encontráronse más a menudo $\mathrm{y}$ en mayor cantidad. La interdependencia entre el hallazgo de anticuerpos y la existencia de lesiones cardiacas fué estadisticamente significativa, tanto respecto a los cinco tipos de anticuerpos como en relación al antimiocárdico y antivalvular solos. La reinfección en el curso de la enfermedad hacía subir las cifras de manera estadisticamente significativa. Hubo un cierto paralelismo entre las cifras de anticuerpos y la actividad del proceso $\mathrm{N}$ reumático, medida por la velocidad de la sedimentación . eritrocitaria y por la reacción de Weltman. En cambio, $N$ no se encontraron anticuerpos algunos en los muy numerosos testigos (dadores de sangre y personal sanitarioy). 